\title{
SPONTANEOUS POLYDOMY IN LABORATORY COLONIES OF THE ANT LEPTOTHORAX CURVISPINOSUS MAYR (HYMENOPTERA; FORMICIDAE)
}

\author{
By Robin J. STUART* \\ Department of Zoology, Erindale College, \\ University of Toronto, Mississauga, Ontario \\ Canada L5L 1 C6
}

\section{INTRODUCTION}

Leptothorax curvispinosus Mayr is a small, common ant in eastern North America where it often nests in such preformed cavities as hollow acorns, hickory nuts, galls, stems and twigs. Its range and nesting preferences overlap broadly with those of two closelyrelated species, L. ambiguus and L. longispinosus (Creighton 1950; Alloway et al. 1982). Colonies within this group are both intra- and interspecifically aggressive; and although normally considered nonparasitic, they occasionally engage in facultative interspecific slavery, apparently by capturing and rearing brood from one another's colonies. Facultative intraspecific slavery may occur more frequently (Alloway 1980). In addition, these species serve as hosts for the obligatory slave-makers Harpagoxenus americanus and L. duloticus (Alloway 1979; for terminology see Stuart and Alloway 1983). All five species coexist in some areas, nest in close proximity to one another, and form dense local populations (Alloway et al. 1982; Del Rio Pesado and Alloway 1983).

Approximately one third $(36.3 \%)$ of individual L. curvispinosus nests (e.g. single acorns) are queenless, while about half $(46.7 \%)$ are monogynous, and the remainder $(17.0 \%)$ are polygynous (Headley 1943; Talbot 1957; Alloway et al. 1982). Dissections have shown that polygyny in this species is more than just a superficial phenomenon with over $90 \%$ of the queens in polygynous nests being inseminated and reproductive. Moreover, young queens often coexist with older queens, indicating that established colonies may

*Present address: Museum of Comparative Zoology Laboratories, Harvard University, Cambridge, Mass. 02138.

Manuscript received by the editor September 19, 1984 
become secondarily polygynous by accepting young queens into their nests (Alloway et al. 1982; for a review of polygyny in ants see Hölldobler and Wilson 1977). The large proportion of queenless nests led Sturtevant (1927) and Talbot (1957) to suggest that colonies may occupy multiple nests (polydomy); and Sturtevant (1927) provided some experimental evidence for this hypothesis by noting that nests found relatively close together in nature were occasionally non-aggressive toward one another. Similar evidence indicates that colonies of L. ambiguus, L. longispinosus and $H$. americanus can be polydomous as well (Alloway et al. 1982; Del Rio Pesado and Alloway 1983).

The discovery of polygyny and polydomy in this group of ants raises numerous questions concerning the structure of colonies and locai populations. Colonies possessing these characteristics may be capable of existing indefinitely, and of spreading out and occupying large areas of suitable habitat. Such "super colonies" are highly developed in other groups of ants with these characteristics (e.g. Formica yessensis Forel, Higashi and Yamuchi 1979). In addition, there are many questions regarding factors which induce polydomy (both proximately and ultimately) and the social ramifications of this colony structure (see Werner et al. 1979). Leptothoracine ants are especially amenable to laboratory culture and provide an unusual opportunity for the experimental study of polydomy. In the present experiment, $L$. curvispinosus colonies (or colony fragments) were collected from individual nests in nature and provided with multiple artificial nests in the laboratory for an extended period of time. The purpose of the experiment was to discover whether colonies would become polydomous (i.e. "bud", see below) spontaneously under relatively simple laboratory conditions.

Traditionally, the term "budding" has been used to refer to true colony fission in which a group of workers and one or more reproductives depart from the parental nest to form an autonomous daughter colony (see Wilson 1971). However, for polydomous species, the term "budding" has also been used to describe the formation of non-autonomous secondary nests which at least initially may be queenless (e.g. Higashi 1976). In general, the relative autonomy of individual nests as reproductive units within polydomous colonies is debatable, and it is possible that such nests occasionally become isolated and achieve full autonomy (see Alloway et al. 
1982). For these reasons, and for convenience, I suggest the continued use of the term "budding" to refer to the formation of daughter nests which contain brood and are spatially distinct from the parental nest, but which may or may not contain reproductives, and which may or may not become truly autonomous.

\section{Materials AND Methods}

The 57 colonies in this experiment were collected in early June from acorns and hickory nuts at several sites in the vicinity of Harpersfield, Ohio. The inhabitants of each nest were treated as separate colonies and established in separate artificial nests and foraging dishes in the laboratory (see Alloway 1979). The artificial nests were composed of two parts. The nest base consisted of the top of a small plastic petri dish $(\mathrm{dia}=4.0 \mathrm{~cm} ; \mathrm{ht}=0.5 \mathrm{~cm})$ painted green and drilled with a small hole $(\mathrm{dia}=0.3 \mathrm{~cm})$ in one side to serve as a nest entrance. The nest lid was made of transparent orange Plexiglas, milled with a groove so as to fit tightly onto the nest base. With the lid in place, the internal volume of these nests was approximately 4 $\mathrm{cm}^{3}( \pm 0.2)$. Each artificial nest was housed in a foraging dish consisting of a large plastic petri dish $(\mathrm{dia}=14.5 \mathrm{~cm} ; \mathrm{ht}=1.5 \mathrm{~cm})$. Each foraging dish also contained a water bottle $(\mathrm{dia}=1.1 \mathrm{~cm}$; length $=$ $3.5 \mathrm{~cm}$ ) stoppered with cotton and held in place at one side of the dish by a dab of plasticene. A microscope slide $(2.5 \times 7.5 \mathrm{~cm})$ served as a food platter in each dish. Water bottles were refilled weekly, and fresh food was added to the food platter 3 times per week. The food was similar to that formulated by Bhatkar and Whitcomb (1970), but was prepared in bulk, frozen, and then thawed prior to use. Food platters were replaced periodically. The colonies were cultured on open laboratory benches illuminated by fluorescent lights mounted approximately $50 \mathrm{~cm}$ above the bench surface and providing an illumination of 1830-2150 lux. A daily photoperiod of $14 \mathrm{~L}: 10 \mathrm{D}$, and a temperature of $22^{\circ} \mathrm{C} \pm 1^{\circ}$ were maintained.

The experiment was initiated in early July, by adding a second artificial nest to each foraging dish, such that the two nest entrances were facing each other, approximately 4-5 cm apart. Each colony was briefly observed for budding on days $1,2,5,11,13,18,29$ and 76 following initiation. A colony was considered to be polydomous if brood was present in both artificial nests when observed. 
Table 1. Census of adults in each nest at the beginning of the experiment: od $=$ dealate queens, $\phi a=$ alate queens, $\hat{\delta}=$ males, $\phi=$ workers $( \pm 2)$. The figure in brackets after the Od count indicates the number of dealate queens that were present in the nest at the time of collection. Asterisks (*) indicate colonies which budded during the experiment (see Figure I).

\begin{tabular}{|c|c|c|c|c|c|c|c|c|c|c|c|c|c|c|}
\hline$\#$ & ㅇd & ㅇa & $\widehat{\partial}$ & $ఫ$ & $\#$ & ㅇd & ㅇa & $\hat{\sigma}$ & $\not$ & $\#$ & 아 & ㅇa & $\hat{\sigma}$ & $\varnothing$ \\
\hline $1 *$ & $2(1)$ & 2 & 0 & 150 & 20 & $1(1)$ & 3 & 0 & 55 & 39 & $1(1)$ & 0 & 3 & 40 \\
\hline 2 & $1(1)$ & 0 & 0 & 45 & 21 & $3(0)$ & 4 & 4 & 35 & 40 & $0(0)$ & 0 & 18 & 15 \\
\hline 3 & $0(0)$ & 0 & 7 & 10 & 22 & $1(1)$ & 0 & 0 & 45 & 41 & $2(1)$ & 0 & 0 & 130 \\
\hline 4 & $11(1)$ & 6 & 0 & 155 & 23 & $1(1)$ & 0 & 0 & 20 & 42 & $9(1)$ & 4 & 28 & 20 \\
\hline $5^{*}$ & $18(1)$ & 8 & 7 & 60 & 24 & $1(1)$ & 1 & 0 & 45 & 43 & $1(1)$ & 0 & 0 & 35 \\
\hline 6 & $3(3)$ & 0 & 0 & 85 & 25 & $2(1)$ & 0 & 0 & 90 & 44 & $3(0)$ & 24 & 1 & 20 \\
\hline 7 & $0(0)$ & 0 & 0 & 70 & 26 & $1(1)$ & 0 & 0 & 50 & 45 & $2(1)$ & 0 & 4 & 90 \\
\hline $8^{*}$ & $0(0)$ & 0 & 5 & 30 & 27 & $2(2)$ & 0 & 0 & 25 & 46 & $3(1)$ & 7 & 0 & 90 \\
\hline 9 & $6(1)$ & 0 & 0 & 75 & 28 & $1(1)$ & 0 & 0 & 50 & 47 & $1(1)$ & 0 & 0 & 30 \\
\hline 10 & $1(1)$ & 0 & 0 & 45 & 29 & $4(1)$ & 0 & 0 & 60 & 48 & $15(1)$ & 4 & 1 & 90 \\
\hline $11^{*}$ & $2(1)$ & 5 & 0 & 75 & 30 & $1(1)$ & 0 & 0 & 50 & 49 & $12(1)$ & 4 & 0 & 55 \\
\hline 12 & $0(0)$ & 8 & 0 & 50 & 31 & $1(1)$ & 0 & 0 & 70 & $50^{*}$ & $2(1)$ & 3 & 1 & 75 \\
\hline 13 & $1(1)$ & 0 & 0 & 105 & 32 & $1(1)$ & 0 & 0 & 95 & 51 & $3(1)$ & 12 & 0 & 30 \\
\hline $14^{*}$ & $1(1)$ & 0 & 0 & 105 & 33 & $1(1)$ & 0 & 0 & 45 & $52^{*}$ & $7(2)$ & 13 & 2 & 90 \\
\hline $15^{*}$ & $6(2)$ & 18 & 0 & 160 & 34 & $1(1)$ & 0 & 0 & 80 & 53 & $3(0)$ & 3 &  & 10 \\
\hline 16 & $0(0)$ & 2 & 11 & 40 & 35 & $1(1)$ & 0 & 0 & 60 & 54 & $0(0)$ & 6 & 2 & 35 \\
\hline $17^{*}$ & $3(2)$ & 0 & 0 & 110 & 36 & $1(0)$ & 5 & 22 & 15 & 55 & $I(0)$ & 8 & 0 & 15 \\
\hline $18^{*}$ & $1(2)$ & 1 & 0 & 130 & 37 & $8(0)$ & 5 & 25 & 15 & 56 & $1(1)$ & 4 & 5 & 55 \\
\hline 19* & $2(1)$ & 5 & 0 & 60 & 38 & $13(0)$ & 7 & 0 & 10 & $57^{*}$ & $14(1)$ & 6 & 0 & 170 \\
\hline
\end{tabular}

Colonies remained undisturbed except for these observations and the normal maintenance indicated above. The data were analysed using Chi-square tests and Student's t-tests. Chi-square tests involving one degree of freedom employed a correction for continuity, and all comparisons of census data with t-tests utilized a square root transformation (Parker 1979).

Census data for each colony are given in Table 1. Between the time the colonies were collected and the initiation of the experiment many of the larger larvae pupated and eclosed to produce workers, alate females and males. Many of the young queens subsequently became dealate, and at least some appeared to function as workers. Nonetheless, males and females were observed flying about in their foraging dishes, and some mating between siblings may have occurred, although none was observed. None of the queens was dissected in this study, and hence the reproductive status of both young and old queens remains unknown. Little colony growth occurred after the initiation of the experiment. 
The queen status of colonies at the beginning of the experiment often differed from their queen status at the time of collection due to the occasional death of queens or the dealation of offspring (see Table 1). At the beginning of the experiment, there was no significant difference in the number of workers present in colonies which were queenless, monogynous or polygynous at that time (t-tests, $P>0.05)$. However, worker numbers at the beginning of the experiment did vary depending on what the queen status of colonies had been at the time of collection, with originally queenless colonies having significantly fewer workers than colonies which had been either monogynous $(\mathrm{t}=4.241, \mathrm{df}=49, P<0.001)$ or polygynous $(\mathrm{t}=3.347, \mathrm{df}=18, P<0.01)$ when collected. This variation will be considered in the analysis of the results.

\section{RESULTS}

During the course of the experiment, 12 of the 57 colonies (21.1\%) became polydomous (see Table 1 and Figure 1). Six colonies were observed to be polydomous on Day 1 (10.5\%); and 2 more became polydomous by Day $2(14.0 \%)$. Thereafter, the number of polydomous colonies fluctuated between 2 and 7 (3.5-12.3\%). Some colonies appeared to remain polydomous only briefly (e.g. \#8, \#19), but others apparently persisted in this condition for long periods (e.g. $\# 1, \# 15, \# 17, \# 52, \# 57$ ) (see Figure 1). One colony (\#52) appeared to remain polydomous for the entire experiment (76 days). Two colonies became polydomous, reverted to monodomy, and then again became polydomous $(\# 14, \# 15)$. Other colonies may also have undergone repeated fissions and fusions between observations.

There was no discernible pattern to how polydomous colonies distributed themselves between the two nests. Often only a few workers and larvae were present in the second nest, but at times large segments of the colonies including dealate queens and alate reproductives could be found in the second nest. The distribution for particular colonies tended to fluctuate between observations, and often the second nest (or the original nest) gradually became depopulated over several days prior to fusion. These kinds of fluctuations indicate that polydomy in these ants is a very dynamic phenomenon and provide considerable scope for future research.

Budding occurred in queenless, monogynous and polygynous colonies containing from 30 to 170 workers (see Table 1), but colony 


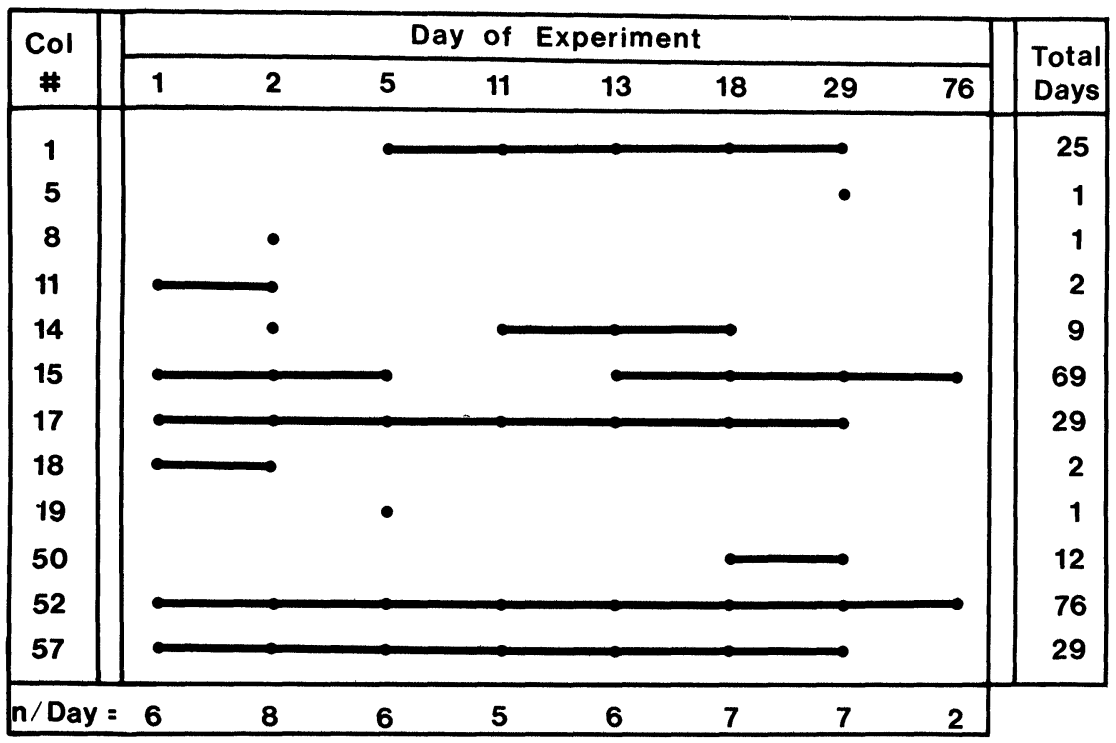

Fig. 1. Occurrence and apparent duration of spontaneous polydomy for all colonies which budded during the course of the experiment. Indicated are colony numbers $(\mathrm{Col} \#)$, day of experiment on which polydomy was observed (Day of Experiment), number of colonies which were polydomous on each observation day (n/Day), and total number of days over which each colony appeared to remain polydomous (Total Days).

size (as indicated by the number of workers) appeared to have a significant influence on polydomy (see Figure 2). Budding occurred in 11 of 26 colonies $(42.3 \%$ ) which contained 60 or more workers, but in only 1 of 31 colonies $(3.2 \%)$ with less than 60 workers $\left(\chi^{2}=\right.$ $9.40, \mathrm{df}=1, P<0.01)$. Overall, colonies which budded were significantly larger than those which failed to do so $(\mathrm{t}=3.554, \mathrm{df}=55, P<$ $0.001)$. This relationship held even if colonies which were queenless when collected $(n=14)$ were omitted from the analysis $(t=3.268$, $\mathrm{df}=41, P<0.01)$; or if colonies which were either queenless $(n=14)$ or polygynous $(n=6)$ when collected were omitted $(t=2.134, d f=$ $35, P<0.05$ ). Among colonies with 60 or more workers there was no significant difference in size between colonies which budded and those which did not $(\mathrm{t}=1.305, \mathrm{df}=24, P>0.05)$. 


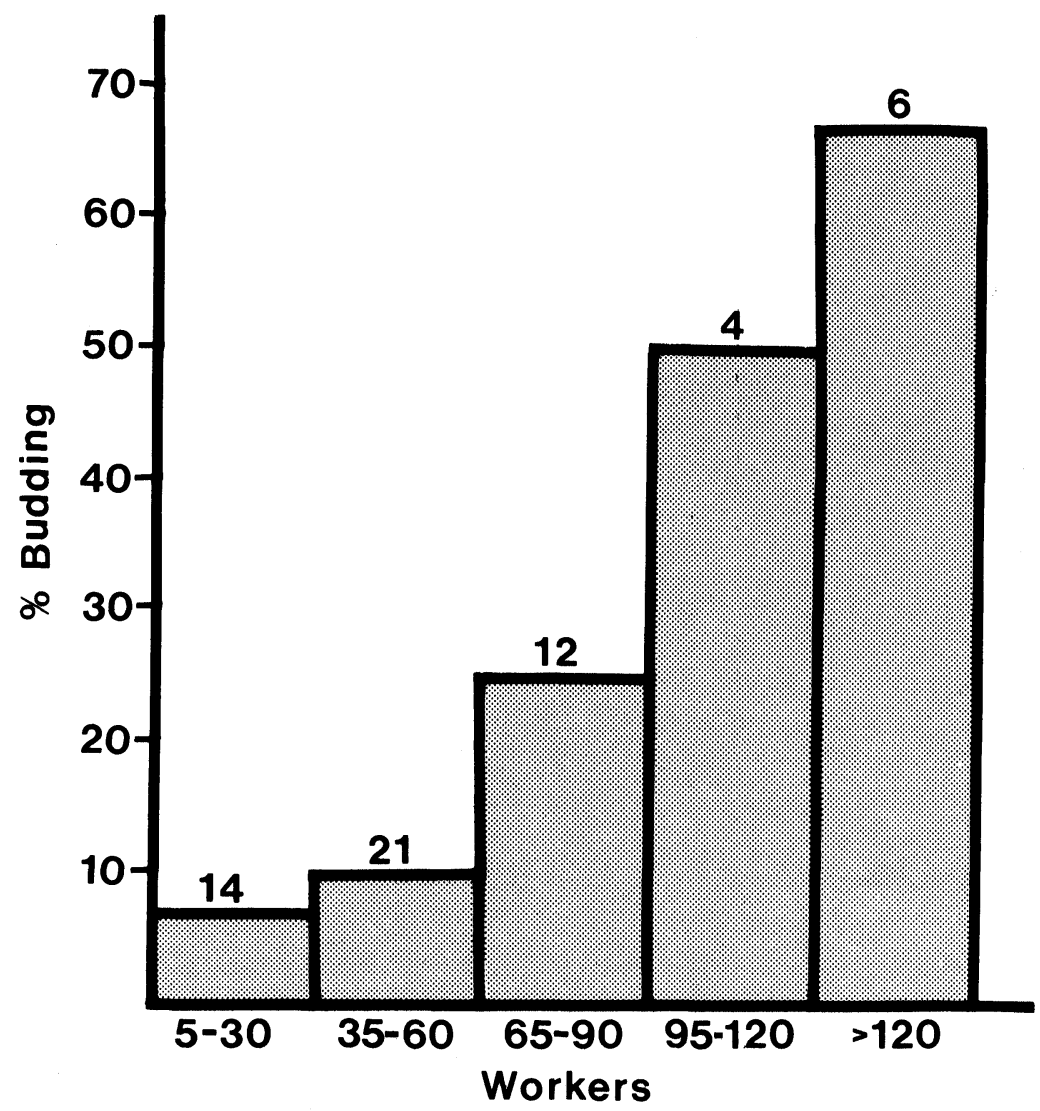

Fig. 2. The relationship between the occurrence of spontaneous polydomy and colony size, as indicated by plotting percent budding relative to the number of workers present. The number of colonies in each size category is indicated above each bar. The significance of this relationship is discussed in the text.

It is possible that polygyny may influence the occurrence of polydomy. In this study only 6 colonies were polygynous when collected; and the 4 of these which budded were fairly large (see Table 1). However, this sample is too small for meaningful statistical comparisons. By the time the experiment was initiated, many colonies had become at least superficially polygynous due to the 
dealation of offspring. However, colonies which were polygynous at this time $(\mathrm{n}=27)$ did not bud more frequently than other colonies $\left(\chi^{2}=2.65, \mathrm{df}=1, P>0.05\right)$; and, within this group, colonies which budded were significantly larger than those which failed to do so $(\mathrm{t}=2.365, \mathrm{df}=25, P<0.05)$.

\section{Discussion}

The results of this study provide further empirical evidence for the existence of polydomy in L. curvispinosus colonies (see Sturtevant 1927). Moreover, these results demonstrate that at least some of the factors which are capable of inducing polydomy in these ants remain active under relatively simple laboratory conditions. The observed relationship between colony size and the occurrence of polydomy suggests that space limitations within nests could be a factor promoting polydomy. Nesting sites such as hollow nuts and twigs might well impose this kind of limitation on colonies in nature. However, other factors associated with colony size, age or maturity could also be involved. Furthermore, it is likely that various factors can effectively induce polydomy in species in which colonies are capable of existing in this condition. In nature, colonies might become polydomous in response to the distribution of food around their nests or to exploit different humidities or temperatures in different nests, perhaps selectively distributing their brood or reproductives in this manner. The present experiment, with its uniform plastic nests and simplistic foraging environment, provided little opportunity for these kinds of factors to operate.

Among leptothoracine ants, a polydomous colony structure could have various important ramifications, depending at least in part on the relative degree of contact between nests within colonies. This colony structure might affect the way in which reproductive rights are apportioned among different queens and workers (see Wilson 1974a, b; Cole 1981; Franks and Scovell 1983), and it might influence the relative susceptibility of colonies to social parasites (see Alloway et al. 1982; Del Rio Pesado and Alloway 1983). Indeed, the combination of polygyny and polydomy is thought to have been an important factor in the evolution of various forms of social parasitism (Buschinger 1970; Alloway 1980).

The existence of polydomy in these ants may explain a peculiar element of their nest emigration behaviour. Möglich (1978) investi- 
gated this behaviour in various Leptothorax species, including $L$. curvispinosus and $L$. longispinosus, and found that these ants typically use both tandem running and adult transport as recruitment techniques during emigrations. Tandem running is a chemical recruitment technique in which one ant leads a single follower between two points. The response is mediated by a pheromone originating in the leader's poison gland and extruded from its sting (see Möglich et al. 1974; Möglich 1979; Stuart and Alloway 1983). Workers which are led to a new nest in this manner subsequently become recruiters themselves and lead or carry other ants to the new nest. However, most colony members, including workers, are merely carried to the new nest, and do not otherwise become involved in the emigration. The unusual element in this nest emigration system is that in many Leptothorax species tandem runs also occur in the reverse direction, from the new nest back to the old nest. Möglich could not rationalize the existence of these "reverse tandem runs" and, using colonies that were emigrating from a single occupied nest to an unoccupied nest, such recruitment appeared to contribute nothing to the efficiency of the emigration. However, if these species are frequently polydomous, emigrations may most commonly occur from one occupied nest to a second occupied nest, and reverse tandem runs could serve to recruit workers from the second nest to assist in the emigration. Thus, the discovery of polydomy may explain the existence of reverse tandem runs; and since this behaviour appears to be so widespread among leptothoracine ants, it is possible that polydomy is also more common than we yet realize.

\section{SUMMARY}

Leptothorax curvispinosus colonies derived from single nests in nature will frequently occupy multiple nests under simplified laboratory conditions. Spontaneous polydomy of this type is apparently related to colony size. When budded, the relative distribution of a colony between alternative nests tends to fluctuate, and repeated fissions and fusions occur. These results provide further experimental evidence for polydomy in this species. 


\section{ACKNOWLEDGMENTS}

I thank T. M. Alloway, J. Carey and P. Boase for their helpful comments and criticisms. Financial assistance was provided by an Ontario Graduate Scholarship to the author and a Natural Sciences and Engineering Research Council of Canada grant to T. M. Alloway.

\section{REFERENC}

Al.toway, T. M. 1979. Raiding behaviour of two species of slave-making ants, Harpagoxenus americanus (Emery) and Leptothorax duloticus Wesson (Hymenoptera: Formicidae). Anim. Behav. 27: 202-210.

Alloway, T. M. 1980. The origins of slavery in leptothoracine ants (Hymenoptera: Formicidae). Amer. Nat. 115: 247-261.

Alloway, T. M., A. Busciungilir, M. Talbot, R. Stuart and C. Thomas. 1982. Polygyny and polydomy in three North American species of the ant genus Leptothorax Mayr (Hymenoptera: Formicidae). Psyche 89: 249-274.

Bilatkar, A., AND W. H. Whitcomb. 1970. Artificial diet for rearing various species of ants. Fla. Ent. 53: 217 232.

Busciungitr, A. 1970. Neue Vorstellungen zur Evolution des Sozialparasitismus und der Dulosis bei Ameisen (Hymenoptera; Formicidae). Biol. Zentralbl. 88: 273 299. (English Translation)

Cot.l., B. J. 1981. Dominance hierarchies in Leptothorax ants. Science 212: 83-84.

Crilinton, W. S. 1950. Ants of North America. Bull. Mus. Comp. Zool. 104: 1585.

Di:i. Rio Plisado, M. G., and T. M. Alloway. 1983. Polydomy in the slavemaking ant, Harpagoxenus americanus (Emery) (Hymenoptera: Formicidae). Psyche 90: $151-162$.

Franks, N. R., AND E. Scovel.l. 1983. Dominance and reproductive success among slave-making ants. Nature 304: 724-725.

Headlik, A. E. 1943. Population studies of two species of ants, Leptothorax longispinosus Roger and Leptothorax curvispinosus Mayr. Ann. Ent. Soc. Am. 36: $743-753$.

HigasiI, S. 1976. Nest proliferation by budding and nest growth pattern in Formica (Formica) yessensis in Ishikari Shore. J. Fac. Sci. Hokkaido Univ. Ser. VI, Zool. 20: 359-389.

Higashi, S., AND K. Yamalicill. 1979. Influence of a supracolonial ant Formica (Formica) vessensis Forel on the distribution of other ants in Ishikari Coast. Jap. J. Ecol. 29: 257-264.

HOI.LOBLIER, B., AND E. O. WIL.SON. 1977. The number of queens: An important trait in ant evolution. Naturwissenschaften 64: 8-15.

Mogl.ICH. M. 1978. Social organization of nest emigration in Leptothorax (Hymenoptera, Formicidae). Ins. Soc. 25: 205-255. 
Mogilicu, M. 1979. Tandem calling pheromone in the genus Leptothorax (Hymenoptera: Formicidae): Behavioral analysis of specificity. J. Chem. Ecol. 5: $35-52$.

Mogilich, M., U. Maschwitz, and B. Holldobler. 1974. Tandem calling: a new kind of signal in ant communication. Science 186: 1046-1047.

PARKI:R, R. E. 1979. Introductory statistics for Biology. Arnold, London. v+ 122 pp.

Stuart, R. J., and T. M. Alloway. 1983. The slave-making ant, Harpagoxenus canadensis M. R. Smith, and its host-species, Leptothorax muscorum (Nylander): Slave raiding and territoriality. Behaviour 85: 58-90.

Sturtivant, A. H. 1927. The social parasitism of the ant Harpagoxenus americanus. Psyche 34: 1-9.

TAi.вot, M. 1957. Population studies of the slave-making ant Leptothorax duloticus and its slave Leptothorax curvispinosus. Ecology 38: 449-456.

Werner, P., F. Catzerlis and D. Cuerix. 1979. A propos du polycalisme che7. Formica (Coptoformica) exsecta Nyl. CR Sect. Fr. UIEIS, Lausanne 7-8 Sept. 1979: $115-126$.

WIL.SON, E. O. 1971. The insect societies. Belknap Press of Harvard University Press, Cambridge, Mass. $x+548 \mathrm{pp}$

WII.SON, E. O. 1974a. Aversive behavior and competition within colonies of the ant Leptothorax curvispinosus. Ann. Ent. Soc. Am. 67: 777-780.

WII.SON, E. O. 1974b. The population consequences of polygyny in the ant Leptothorax curvispinosus. Ann. Ent. Soc. Am. 67: 781-786. 

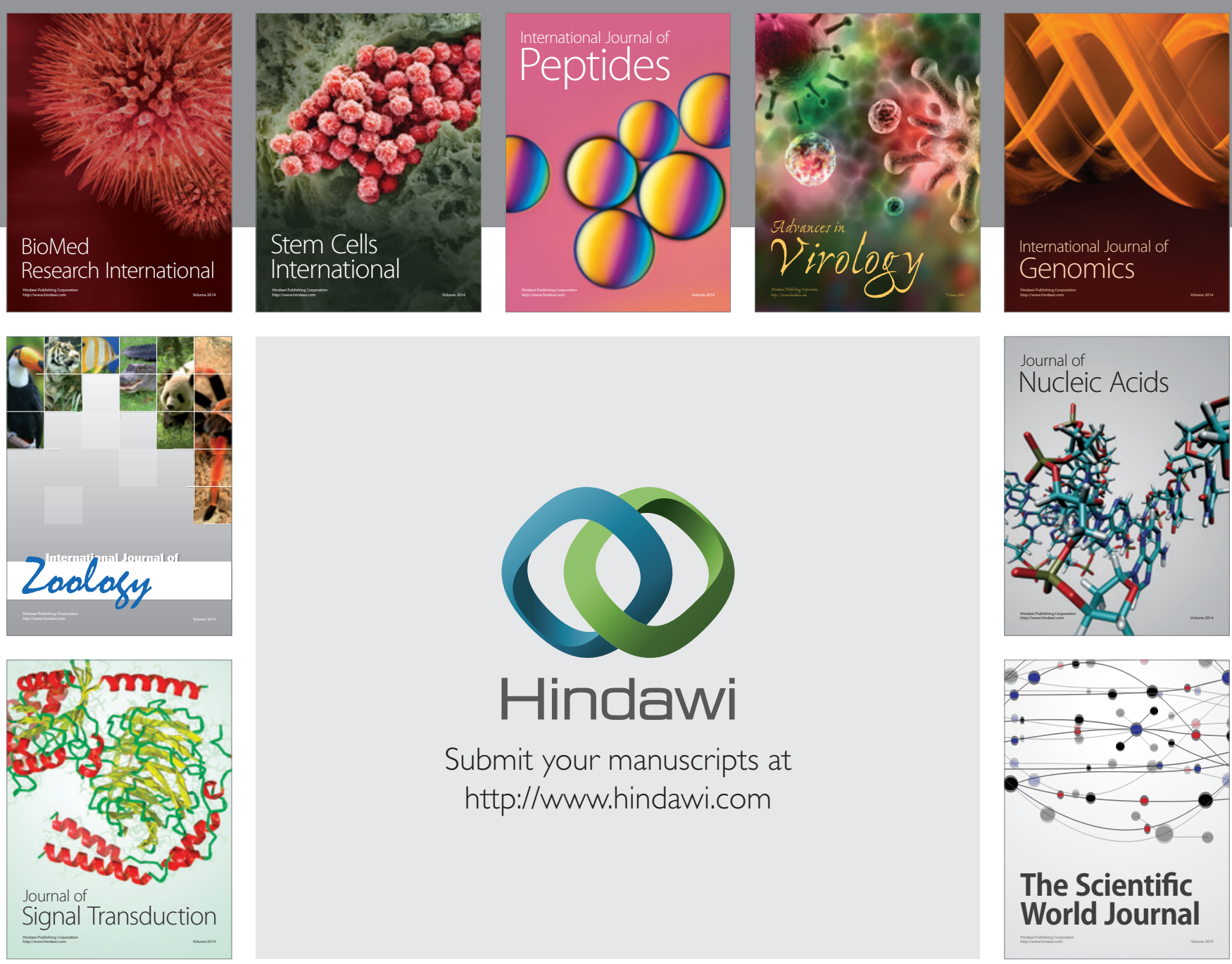

Submit your manuscripts at

http://www.hindawi.com
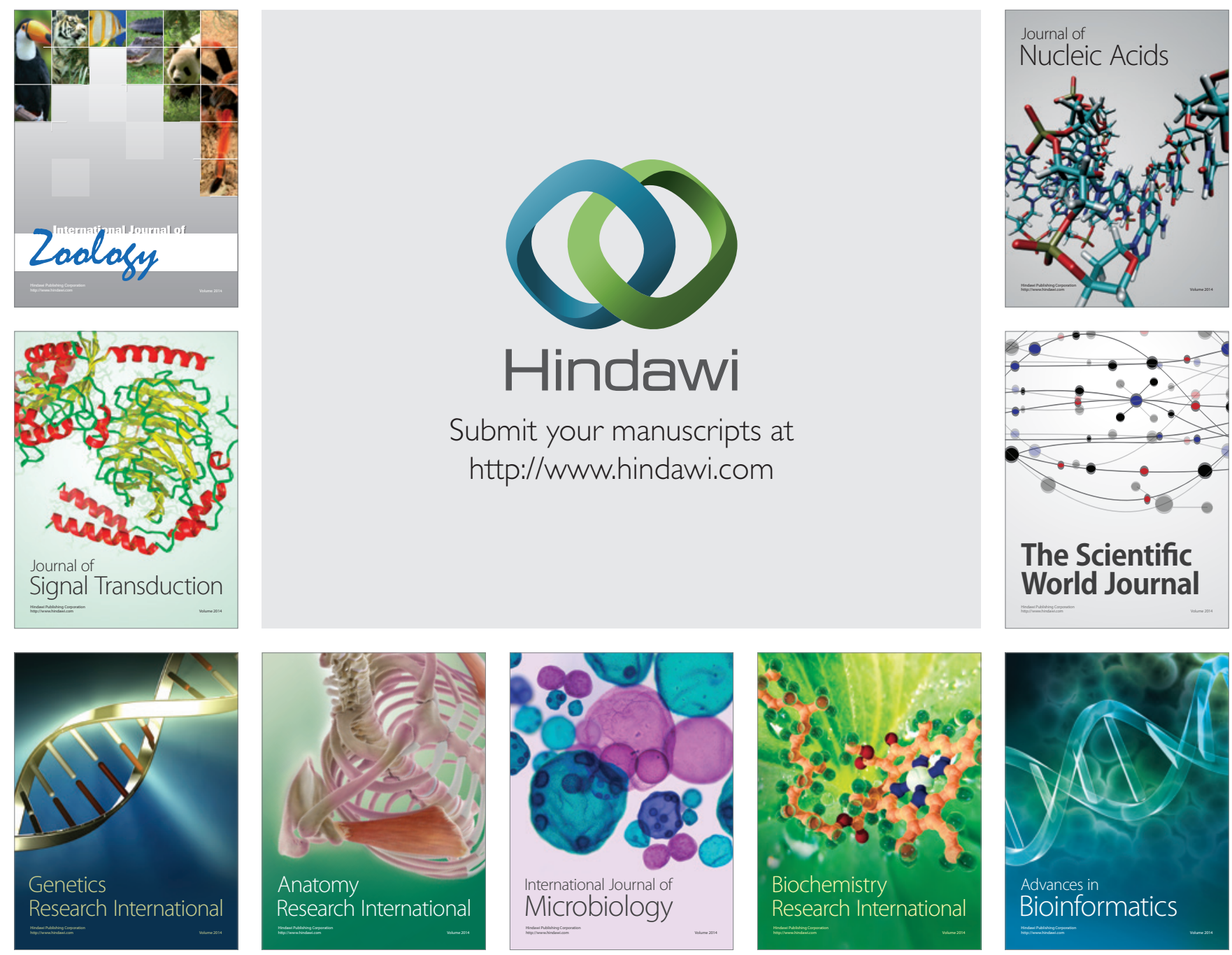

The Scientific World Journal
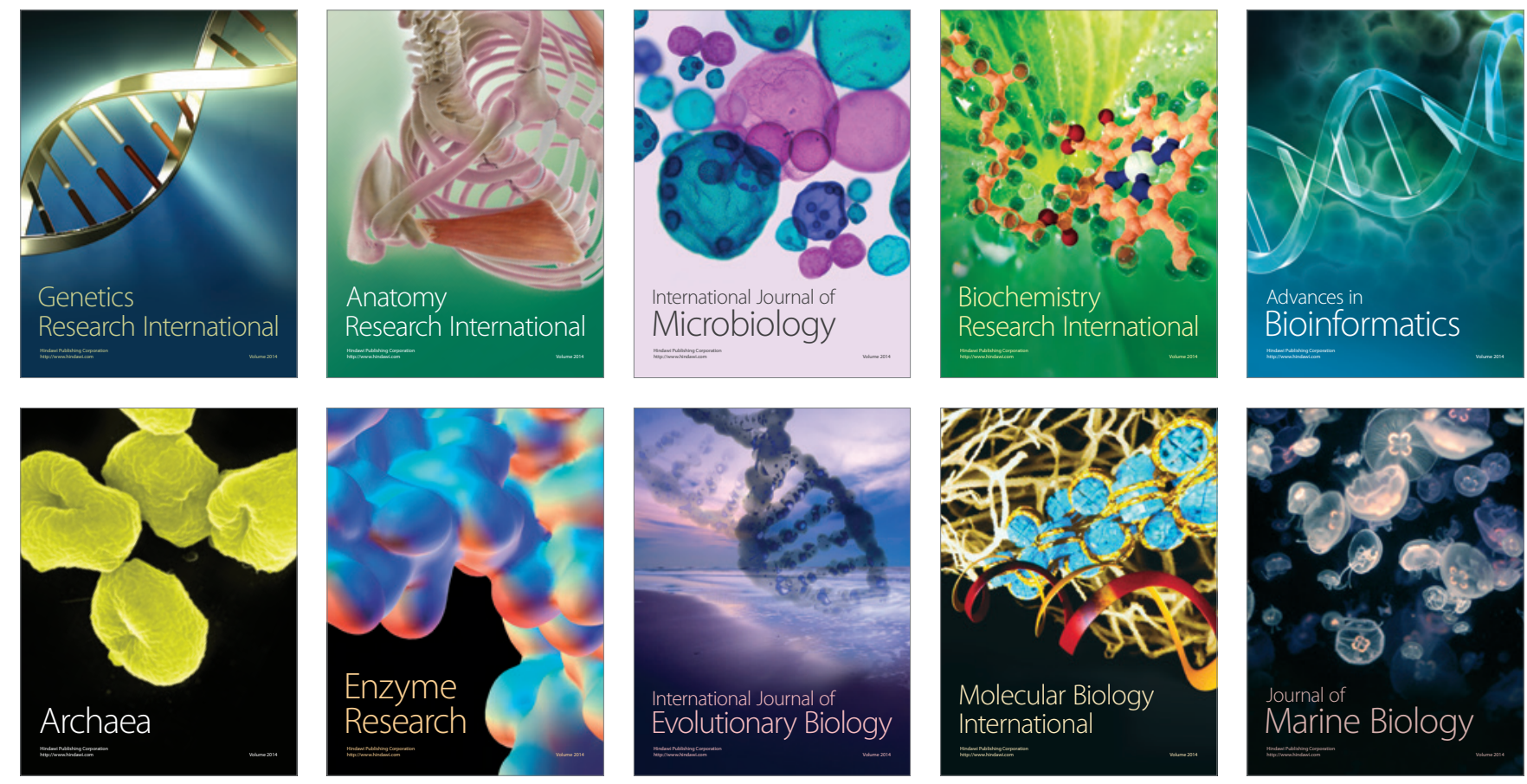